Animal Health Research Institute, El - Fayoum lab.

\title{
LISTERIA ORGANISMS AS BACTERIAL PATHOGENS IN MILK AND SOME DAIRY PRODUCTS IN FAYOUM GOVERNORATE
}

(With 3 Tables)

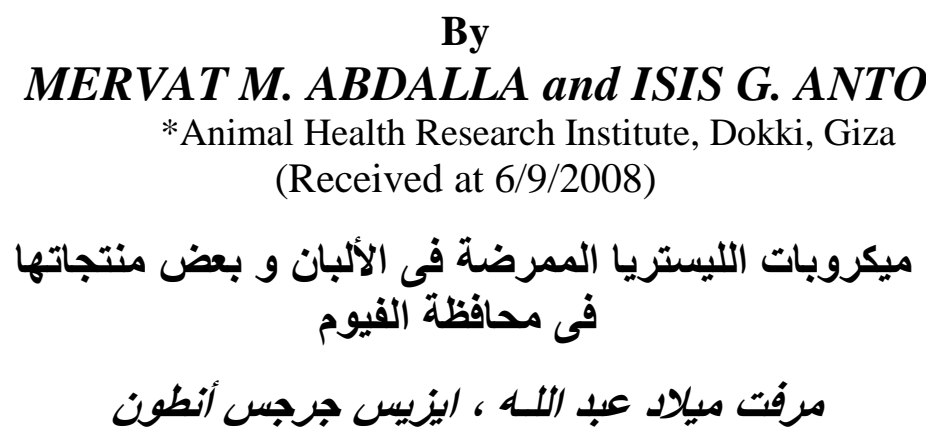

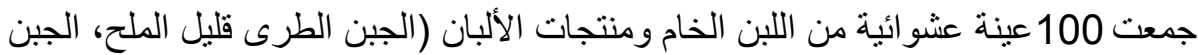

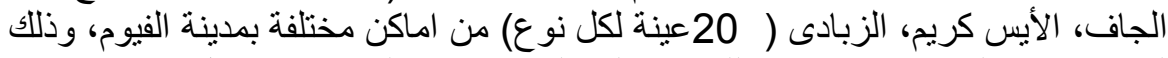

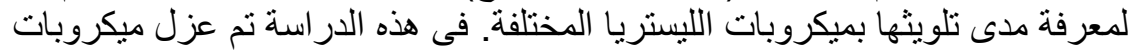

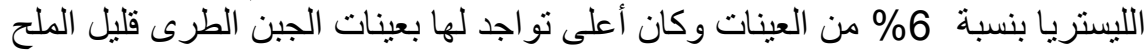

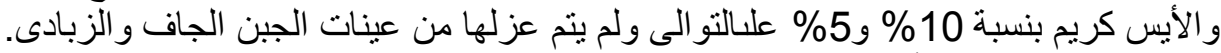

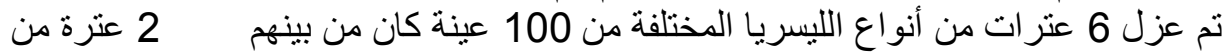

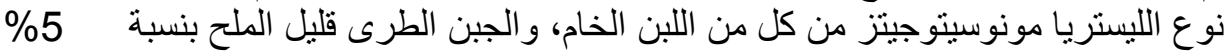

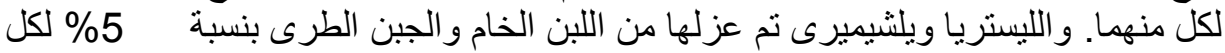

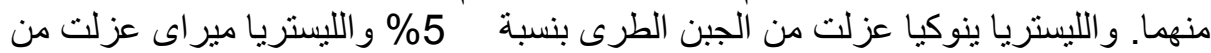

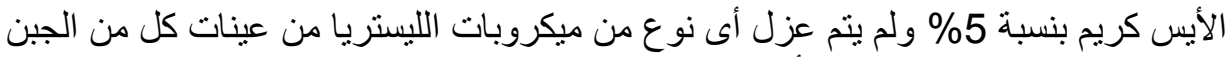

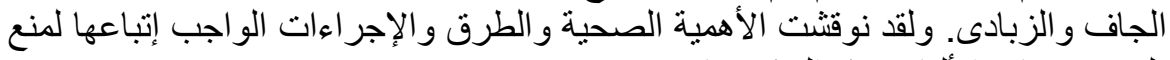
تلوث منتجات الألبان بهذه الميكروبات.

\section{SUMMARY}

A total of 100 random samples of raw milk and some dairy products (low salt soft cheese, hard cheese, ice cream and yoghurt, 20 samples each) were collected from different localities in Fayoum city and examined for the presence of Listeria spp. In this investigation the recovery rate of Listeria from the examined samples was 6\%. The highest incidence of Listeria species was recovered from low salt soft cheese $15 \%$ followed by raw milk and ice cream samples with incidence of $10 \%$ and $5 \%$, respectively. A total of 6 Listeria species were isolated from the examined 100 samples. From 6 Listeria isolates, 2 isolates were 
identified as L. monocytogenes isolated from raw milk and low salt soft cheese. 2 isolates were identified as L. welshimeri from raw milk and low salt soft cheese. one isolate was identified as L. innocua from low salt soft cheese and one isolate was identified as $L$. murrayi from ice cream. The public health importance and the sanitary measures for control of Listeria spp. were mentioned.

Key words: Dairy products, milk, Listeria

\section{INTRODUCTION}

The importance of Listeria as a foodborne pathogen has become increasingly apparent since the outbreaks reported in North America. The epidemics, which have been associated with pasteurized milk (Fleming et al., 1985) and Mexican-style cheese (James et al., 1985) have prompted concern about the survival and growth characteristics of Listeria in contaminated food stuffs during cold storage.

Currently seven species are known in the genus Listeria, L. monocytogenes, L. seeligeri, L. welshimeri, L. innocua, L. murrayi, $L$. grayi and L. ivanovi. The most important human pathogen in the genus is L. monocytogenes which is a facultative intracellular Grampositive bacterium responsible for listeriosis a sever foodborne illness which may result in meningitis, septicemia, spontaneous abortion and gastroenteritis (Anonymous, 2000).

In domestic animals Listeria organisms can cause circling disease, encephalitis, septicaemia, mastitis and abortion (Rosenow and Marth, 1987).

This association with food together with the unique ability of Listeria to grow under a wide variety of food processing conditions including: refrigeration temperature (Palumbo and Williams, 1991, Gougouli et al., 2008), its tolerance of moderate to high sodium chloride levels (Feresu and Jones, 1988), sodium nitrate (Shahamat et al., 1980) and a wide $\mathrm{pH}$ range (George et al., 1988, Belessi et al., 2008), its growth in the presence or absence of oxygen (Linton et al., 1995) and a high heat resistance compared to most other non spore forming food borne pathogens (Gervilla et al., 1997) have prompted to study the occurrence of the organism in milk and other dairy products.

Therefore, the objective of the present work was planned to:

- Study the distribution of Listeria organisms associated with dairy products by bacteriological examination of raw milk, cheese, ice cream and yoghurt samples. 


\section{MATERIALS and METHODS}

\section{1- Collection of samples:}

A total of 100 samples of raw milk and some diary products (low salt soft cheese "Talaga"), hard cheese (Romy), Ice cream and yoghurt were randomly collected from different markets and dairy shops in Fayoum Governorate. The samples were collected in clean sterilized equipments and taken under aseptic conditions, and transferred to the lab in an ice box, where they were examined for the presence of Listeria microorganisms.

2- preparation of samples: according to Marth (1978).

a- Raw milk: The sample was well agitated before examination.

b- Cheese: The sample must be representative of the food's outer surface as well as its interior part.

c- Ice cream: A homogenate was prepared by holding the ice cream container in a water bath at $42^{\circ} \mathrm{C}-45^{\circ} \mathrm{C}$ for not more than 15 minutes.

d- Yoghurt: Samples were prepared following the technique described by APHA, (1992).

\section{3- Isolation and identification of Listeria spp:}

The technique recommended by Federal Register (1988) was adopted by selective enrichment in Listeria enrichment broth (LEB), followed by Fraser's secondary enrichment broth (F.B), after 24-48 hours were streaked onto Oxford agar Plates (Curtis et al., 1989).

Suspected colonies of Listeria were picked up and purified before being identified according to Hitchins (1995).

\section{RESULTS}

Table 1: Prevalence of Listeria spp. in the examined raw milk and some milk products

\begin{tabular}{|l|c|c|c|}
\hline \multirow{2}{*}{ Types of samples } & \multirow{2}{*}{$\begin{array}{c}\text { Number of } \\
\text { examined samples }\end{array}$} & \multicolumn{2}{c|}{ Positive samples } \\
\cline { 3 - 4 } & 20 & 2 & $\%$ \\
\hline 1- Raw milk & 20 & 3 & 10 \\
\hline $\begin{array}{l}\text { 2- Low salt soft cheese } \\
\text { (Talaga) }\end{array}$ & 20 & 0 & 0 \\
\hline 3- Hard cheese (Romy) & 20 & 1 & 5 \\
\hline 4- Ice cream & 20 & 0 & 0 \\
\hline 5- Yoghurt & 100 & 6 & 6 \\
\hline Total & & & \\
\hline
\end{tabular}


Table 2: Percentage distributions of Listeria species in the examined raw milk and some milk products.

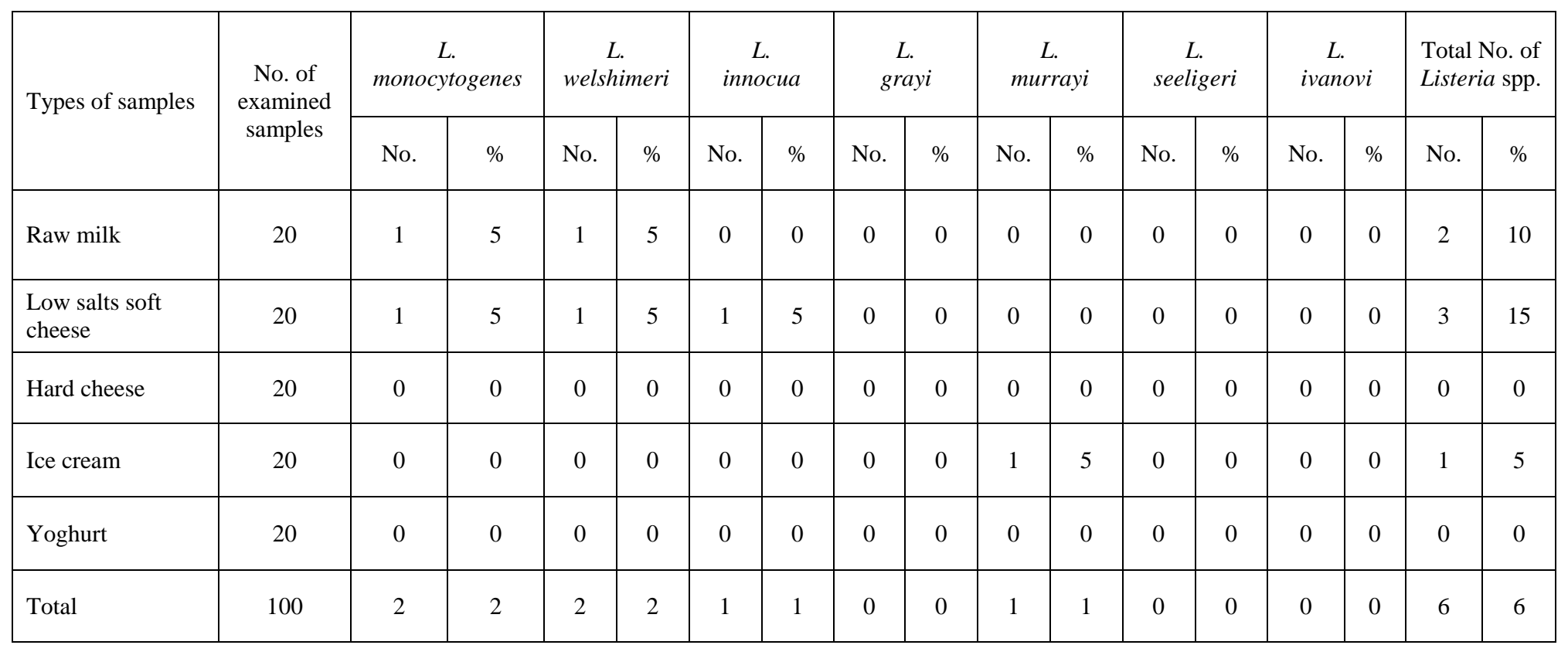


Table 3: Prevalence rate of Listeria species in the examined raw milk and some milk products samples.

\begin{tabular}{|l|c|c|c|c|c|c|c|c|c|c|}
\hline \multirow{2}{*}{ Lesteria spp. } & \multicolumn{9}{|c|}{ Types of samples } \\
\cline { 2 - 13 } & \multicolumn{2}{|c|}{ Raw milk } & $\begin{array}{c}\text { Low salt soft } \\
\text { cheese }\end{array}$ & \multicolumn{1}{|c|}{ Hard cheese } & \multicolumn{2}{|c|}{ Ice cream } & \multicolumn{2}{c|}{ Yoghurt } \\
\cline { 2 - 12 } & No. & $\%$ & No. & $\%$ & No. & $\%$ & No. & $\%$ & No. & $\%$ \\
\hline L. monocytogenes & 1 & 50 & 1 & 33.3 & 0 & 0 & 0 & 0 & 0 & 0 \\
\hline L. welshimeri & 1 & 50 & 1 & 33.3 & 0 & 0 & 0 & 0 & 0 & 0 \\
\hline L. innocua & 0 & 0 & 1 & 33.3 & 0 & 0 & 0 & 0 & 0 & 0 \\
\hline L. murrayi & 0 & 0 & 0 & 0 & 0 & 0 & 1 & 100 & 0 & 0 \\
\hline Total & 2 & 100 & 3 & 100 & 0 & 0 & 1 & 100 & 0 & 0 \\
\hline
\end{tabular}

\section{DISCUSSION}

Listeriosis is listed among the zoonotic diseases there is sufficient evidence to prove that listeriosis is primarily a foodborne disease. Dairy products currently have stronger association with listerosis than other types of food with both raw and pasteurized milk as well as certain cheese have been identified as causes of food poisoning outbreaks. (Fleming et al. 1985, James et al. 1985, Jayarao et al. 2006).

Among raw milk samples as shown in Table: 1 Listeria was isolated with an incidence $10 \%$ this is supported by the result of Slade and Collins-Thompson, (1988) and Farber et al. (1988) who found a total of 11-14\% Listeria species from raw milk. A lower incidence $2.2 \%$ of Listeria species in raw milk was recorded by Hamdallah and Ahmed (2007).

In Table: 2 L. monocylogenes was isolated from $5 \%$ of examined raw milk samples. This incidence was nearly similar to that reported in a study carried out by Slade and Collins-Thompson (1988) who found an incidence of $5.9 \%$ L. monocytogenes from raw milk. Liewen and plautz (1988), Laura and Elmer (1990) and Macrae et al. (1993) recorded that L. momocylogenes was present in about $4 \%$ of the examined raw milk samples. Meanwhile, Kovincie et al. (1979) and Hamdallah and Ahmed (2007) isolated L. monocytogenes respectively from $3.2 \%$ and $1.6 \%$ raw milk samples.

A higher incidence of L. monocytogenes in milk was recorded by Hayes et al. (1986) 15\%, Garayzabal et al. (1987) $14.3 \%$ to $75 \%$ and Oliveira et al. (1998) 8\%. 
The results given in Table 2 revealed that L. welshimeri $5 \%$ was isolated from raw milk samples thus finding go hand in hand with the finding of Kamel (1996) who recovered L. welshmeri from raw milk samples. No other species could be isolated from raw milk samples. These results were compatible with that results obtained by Farber et al. (1988) and Lund et al. (1991), while Gaya et al. (1998) isolated them from milk samples.

The incidence of Listeria species appears to vary from survey to another. This may be dependent upon factors such as, the method used for isolation, the geographic location, seasonal variation and milk quality (Garayzabal et al. 1987, Farber et al. 1988, and Lund et al. (1991).

Milk is generally bacteria free when it comes from the udder of healthy cow (Frazier and Westhoff, 1998), but Listeria may enter the milk supply in several ways. The main source of Listeria in milk is probably fecal contamination (Macrae et al. 1993).

In Table 1 Listeria was recovered from $15 \%$ of low salt soft cheese. Terplan et al. (1986) isolated Listeria species from soft cheese with incidence of $10.2 \%$, While Vitas and Garcia (2004) isolated them with incidence of $8.11 \%$. Furthermore surveys in a number of countries have shown that Listeria may be a common contaminant of soft cheese (Farber and Peterkin, 1991; Zottola and Smith, 1991 and Eppert et al. 1997).

Table 2 illustrated that L. monocytogenes, L. welshimeri and L. inncoua were isolated from low salt soft cheese samples with an incidence of $5 \%$ from each of them. Silva et al. (1998) detected $L$. monocytogenes (10.6\%), L. innocua (12.6\%). Rota et al. (1992) isolated L. innocua from soft cheese.

No Listeria species could be isolated from hard cheese samples. Similar observations were recorded by El-Sukhon, (1993). On rare occasions, hard cheese have become contaminated with Listeria (Macrae et al. (1993). This may be attributed to the presence of high levels of lactic acid and low pH values (Ryser et al. 1985 and Marth, 1998).

One approach to reduce the prevalence of Listeria in cheese is the application of bacteriocin producing starter cultures that show antagonistic properties towards Listeria organisms (Joosten et al. 1995).

Junttila et al. (1988) and Macrae et al. (1993) demonstrated the resistance of Listeria to freezing. Among ice cream products Listeria was isolated with a percentage of 5\%, also Marcae et al. (1993), Dean and Zottola (1996) isolated Listeria from ice cream samples in the same percentage. 
In Table 2 the incidence of $L$. murrayi in ice cream was $5 \%$. Coincides with Cox et al. (1989) who detected Listeria species in the environment of ice cream production.

Greenwood et al. (1991) reported that ice cream occasionally contains Listeria species. Rosenow and Marth, (1987) recorded that ice cream has been implicated but never directly involved in causing human listerosis. WHO working group (1988) who concluded that the incidences of L. monocytogenes in ice cream varied from 0 to $5.5 \%$ with very low levels of Listeria organisms (1-15 cfu/gm). Gougouli et al. (2008) found that under chilling conditions L. monocytogenes grew well at all temperature tested $\left(4\right.$ to $\left.16{ }^{\circ} \mathrm{C}\right)$ in ice cream samples. Under freezing conditions $\left(-5\right.$ to $\left.-33^{\circ} \mathrm{C}\right)$ no significant changes in the inoculum levels tested $\left(10^{3}\right.$ and $\left.10^{6} \mathrm{cfu} / \mathrm{g}\right)$ of L. monocytogenes in ice cream samples.

The results recorded in Table 1 proved that Listeria species could not be detected in any of 20 examined samples of yoghurt. Similar results were obtained by Kerr et al. (1992), Rola et al. 1994, Abou Eleinin (1999) and El-Prince (1999). The failure of these organisms to grow in yoghurt may be due to the presence of lactic acid production and the resultant lowering $\mathrm{pH}$ value of such products (Huang et al. 1993 and Marth, 1993).

On the other hand, GreenWood et al. (1991) isolated L. monocytogenes from one sample (2.13\%) out of 47 yoghurt samples and the authors attributes the presence of Listeria species in yoghurt to the post processing contamination from the plant environment.

Although, milk used to produce the industrially fermented milk is pasteurized, contamination of the product with L. monocytogenes may occur after pasteurization if complex and less easily cleaned equipments are used in packaging, filling rooms or if bulk starter cultures are contaminated with organisms (Charlton et al. 1990).

Dairy products are involved in several outbreaks of listeriosis, so the identification of Listeria species in milk and dairy products could be very important for human health. L. monocytogenes has been involved in several outbreaks and sporadic cases of diseases associated with the consumption of pasteurized milk and other dairy products (Van Kassel et al. 2004, Makino et al. 2005).

There were 36 cases of listeriosis in France which were linked to Briede Meaux a soft cheese made from raw milk, in this case no deaths were recorded Leile et al. (2006). 
It's estimated that 2500 L. moncytogenes infections occur in the USA each year. The L. monocytogenes detection rates observed in the cheese samples monitored after packing and at the end of the shelf life were $2.1 \%$ and $4.8 \%$, respectively (Manfreda et al. 2005). The presence of $L$. monocytogenes in milk-based products can be related to raw milk contamination or to post-pasteurization contamination (Carminati et al. 2004).

In conclusion, from this work it is clear that contamination of dairy products by Listeria spp. especially L. monocytpgenes from the view point of a potential health hazard should not be ignored. Listeria could contaminate the dairy products through raw milk used without sufficient heat treatment or through contamination of equipments used for the preparation or distribution of the products. Therefore, application of good hygienic measures during production, storage and distribution of such products are essential to safe products quality, consequently prevent the risk of human hazards. It is important for food hygienists and employees working in the field of production of dairy products to understand the pattern of microbial growth specially those of public health concern such as L. monocytogenes in order to safeguard consumers.

\section{REFERENCES}

A.P.H.A. (American Public Health Association) (1992): Compendium of Methods for the Microbiological Examination of Food. $3^{\text {rd }}$ Ed. American Public Health association, Washington, D. C. USA.

Abou-Eleinin, A.M. (1999): Studies on Listeria species in milk and milk products. Ph. D. Thesis, Fac. Net. Med., Zagazig Univ., Egypt.

Anonymous (2000): Rapport la commission d'tude derisques lies a $L$. monocytogenes, Juillet 2000, AFSSA. Maisons Alfort agence Francaise de Securite Sanitaire des Aliment., pp.143.

Belessi, C.I.; Papanikolaoa, S.; Drosinos, E. and Skandamis, P. (2008):

Survival and resistance of Listeria innocua in Feta cheese and yoghurt in the presence or absence of fungi. J. Food Prot., 71 (4): 742-749.

Carminati, D.; Perrone, A.; Giraffa, G.; Neviani, E. and Muchetti, G. (2004): Characterization of L. monocytogenes strains isolated from Gorganzola cheese rinds. Food Microbiol., 21 (61): 801807. 
Charlton, B.R.; Kinde, H. and Jensen, L.H. (1990): Environmental survey for Listeria species in California milk processing plants. J. Food Prot., 53: 198-201.

Cox, L.J.; Kleiss, T.; Cordier, J.L.; Cordellana, C.; Konkel, P.; Pedazzini, C.; Beumer, R. and Srebenga, A. (1989): Listeria species in food processing, nonfood and domestic environments. Food Microbiol., 6: 49-61.

Curtis, G.D.; Mitchell, R.G.; King, A.F. and Griffin, E.J. (1989): A selective differential medium for the isolation of Listeria monocytogenes. Lett. Appl. Microbiol., 8: 95-98.

Dean, J.P. and Zottola, E.A. (1996): Use of nisin in ice cream and effect on the survival of Listeria monocytogenes. J. Food Prot., 59: 476-480.

El-Prince, Enas, M. (1999): Isolation of Listeria monocytogenes and other Listeria species from milk and some dairy products. Assuit Vet. Med. J., 40: 168-176.

El-Sagheer, M.A. (1990): Isolation of L. monocytogenes from Bulk and milk cans, Egypt. Vet. Sci., 27: 109-115.

El-Sukhon, S.N. (1993): Bacteriological analysis of white Brined (Nablusian) cheese with reference to $L$. monocytogenes in Jordan. J. Egypt. Vet. Med. Ass., 53 (1\&2): 139-144.

Eppert, I.; Valdes-Stauber, N.; Gotz, H. and Busse, M. (1997): Growth reduction of Listeria Species caused by undefined industrial Red smear cheese cultures and bacteriocin-producing Brevibacterium Lilnens as evaluated in situ on soft cheese. Appl. And Environ. Microbiol., 63 (12): 4812-4817.

Farber, A.M.; Sanders, G.W.; Spiers, J.I.; D'Aoust, J.Y.; Emmons, D.B. and McKellar, R. (1988): Thermal resistance of Listeria monocytogenes in inoculated and naturally contaminated raw milk. Int. Food Microbiol., 7: 277-286.

Farber, J.M. (1989): Listeria monocytogenes, a food-borne pathogen. Microbiol. Rev., 55: 476-511.

Farber, J.M. and Peterkin, P.I. (1991): Listeria monocytogenes: A foodboene pathogen. Microbial Rev., 55: 476-511.

Federal Register (1988): Bacteriological Analytical Manual, Ch.29, Listeria isolation, revised method of analysis. Fed. Regist., 55: 44153-44158.

Feresu, S.B. and Jones, D. (1988): Taxonomic studies on Brochothrix, Erysipelothrix, Listeria and atypical lactobacilli. J. Gen. Microbiol., 134: 1165-1184. 
Fleming, D.W.; Cochi, S.L.; MacDonald, K.L.; Broome, C.V. and Reingold, A.L. (1985): Pasteurized milk as vehicle of infection in an outbreak of Listeriiosis. New-England J. Med., 312 (7): 404407.

Frazier, W.C. Westhoff, D.C. (1998): Food Microbiology, $4^{\text {th }}$ Ed. Mc. Graw-Hill, Inc. New York.

Gaya, P.; Sanchez, J.; Medina, M. Murez, M. (1998): Incidence of L. monocytogenes and other Listeria species in raw milk produced in Spain Food microbial., 15(5):521-522.

George, S.M.; Lund, B.M. and Brocklehurst, T.F. (1988): The effects of $\mathrm{pH}$ and temperature on initiation and growth of Listeria monoctogenes. Lett. Appl. Microbiol., 6:153-156.

Gervilla, R.; Capellas, M.; Ferragut, V. and Guamis, B. (1997): Effect of high hydrostatic pressure on Listeria innocua 910 CECT inoculated into ewe's milk. J. Food Prot., 60 (1): 33-37.

Gougouli, M.; Angelrdis, A.S. and Koatsoamanis, K. (2008): A study on the kinetic behavior of L. monocytogens in ice cream stored understatic and dynamic chilling and freezing conditions. Dairy Sci., 91: 523-530.

Garayzabal, J.F.F.; Rodriguez, L.D.; Boland, J.A.V.; Ferri, E.F.R.; Diestre, V.B.; Cancelo, J.L.B. and Fernandez, G.S. (1987): Survival of Listeria monocytogenes in raw milk treated in a pilot plant size pasteurizer. J. Appl. Bact., 63: 533-537.

Greenwood, M.H.; Roberts, D. and Burden, P. (1991): The occurrence of listeria species in milk and dairy products: a national survey in England and Wales. Int. j. Food Microbiol., 12 (2-3):197-206.

Hamdallah, M. and Ahmad, A.M. (2007): Incidence of Listeria spp. in raw milk in Shahrekord, Iran. Foodboene Pathogens and Disease. 4 (1) $107-110$.

Hayes, P.S.; Feeley, J.C.; Graves, L.M.; Ajello, G.W. and Fleming, D.W. (1986): Isolation of L. monocytogenes from raw milk. Appl. Environ. Microbiol., 51 (2): 438-440.

Hitchins, A.D. (1995): Listeria monocytogenes. In: $8^{\text {th }}$ Ed. Food and Drug Administration. Bacteriological Analytical Manual. AOAC International Pub. Co., Gaithersburg, MD, USA.

Huang, J.; Lacroix, C.; Daba, H. and Simard, R.E. (1993): Inhibition of growth of Listeria strains by mesenterocin 5 and organic acids. Lait. 73: 357-370. 
James, S.M.; Fannin, S.L.; Agree, B.A.; Hall, B.; Parker, E.; Vogt, J.; Run, G.; Williams, J.; Lieb, L.; Salminen, C.; Prendergast, T. Werner, S.B. and Chin, J. (1985): Listeriosis outbreaks associated with Mexican-style cheese. California morbid. Mortal. Weekly Report. (34):357-459.

Joosten, H.M; Gaya, P. and Nuenz, M. (1995): Isolation of tyrosine decarboxylase mutant of bacteriocin-Producing Enterococcus faecalis strain and their application in Cheese. J. Food Prot.,58: 1222-1226.

Junttila, J.R.; Niemela, S.I. and Hirn, J. (1988): Minimum growth temperature of Listeria monocytogenes and non-haemolytic Listeria. J. Appl. Bact., 65(4): 321-327.

Kamel, N.M. (1996): Incidence of L. monocytogenes in milk and some dairy products. Ph.D. Thesis. Faculty Vet. Med. Cairo Univ.

Kerr, K.G.; Rotowa, N.A. and Hawkey, P.M. (1992): Listeria in Yoghurt. J. Nutri. Med., 3: 27-29.

Jayarao, B.M.S.C.; Donaldson, B.A.; Straley, A.A.; Sawont, N.V.; Hegde, N.V. and Brown, J.L. (2006): A survey of foodborne pathogens in bulk tank milk and raw milk consumption among farm families in Pennsylvania. J. Dairy Sci., 89: 2451-2458.

Kovincie, I.; Stajner, B.; Zakula, S.; Galie, M. (1979): The findings of L. monocytogenes in the milk of cow from infected herds. Ivanovied. Proceeding of the Seventh International Symposium (on Listeriosis). National Agroind Ustrial Union Center for Scientific Information. Sofia. 221-224.

Laura. J.P. and Elmer, H.M. (1990): L. monocytogenes- threat to a safe food supply. J. Dairy Sci., 73: 912-928.

Leile, P.; Rodriques, R.; Ferreire, M.; Ribeiro, G.; Jacquet, C.; Martin, $P$. and Brito, L. (2006): Comparative characterization of $L$. monocytogenes isolated from Prtugues farm house. Int. J. Food Microbiol., 106: 111-121.

Liewen, M.B. and Plautz, M.W. (1988): Occurrence of L. monocytogenes in raw milk in Nebraska. J. Food Prot., 51: 840-841.

Linton, R.H.; Carter, W.H.; Pierson, M.D.; Hackney, C.R. and Eifert, J. $D$. (1995): Use of Modified Gompertz equation to predict the effects of temperature, $\mathrm{pH}$ and $\mathrm{NaCl}$ on the inactivation of Listeria monocytogenes scott A heated in infant formula. J. Food Prot., 59 (1): 16-23. 
Lovett, J.; Francis, D.W. and Hunt, J.M. (1987): Listeria monocytogenes in raw milk: Detection, Incidence, and pathogenicity. J. Food Prot., 50: 188-192.

Lund, A.M.; Zottola, E.A. and Pusch, D.J. (1991): Comparison of methods for isolation of Listeria from raw milk. J. Food Prot., 54 (8):602-606.

Macrae, R.; Robinson, R.K. and solder, M.J. (1993): Encyclopedia of food science, Food Technology and Nutrition. Vol. 4 by Academic Press Limited 24/2 oval road London.

Makino, S.L.; Kawamoto, K.; Ta Keshi, K.; Okada, R.; Yamasaki, M.; Yamamoto, S. and Igini, S. (2005): An outbreak of foodborne Listeriosis due to cheese in Japan, during 2001. Int. J. Food Microbiol., 104: 189-196.

Manfreda, G.; Alessandra, D.C.; Stella, S.; Cozzi, M. and Contoni, C. (2005): Occurrence and ribotypes of L. monocytogenes in Gorgonzola cheese. Int. J. Food Microbiol., 102 (3): 287-293.

Marth, E.H. (1978): Standard Methods for the Examination of Dairy Products $14^{\text {th }} \mathrm{Ed}$. By interdisciplinary books \& periodicals for the professional and the layman.

Marth, E.H. (1993): Growth and survival of Listeria monocytogenes, Salmonella species and Staphylococcus aureus in the presence of sodium chloride. Dairy Food and Environ., 23 (10): 40-46.

Marth, E.H. (1998): Survival of Listeria on dairy foods. Proceedings of the Annual Spring Meeting of the Food Research Institute, University of Wisconsin-Madison, May: 25-26.

Oliveira, A.N.; Mesquita, A.J.; Nunes, I.A.; Silva, T.J.P. and Lage, M.E. (1998): Occurrence of Listeria in raw and pasteurized milk in Goiania, Goias. Revista Brasileria de Ciencia Veterinaria, 5 (2): 55-58.

Palumbo, S.A. and Williams, A.C. (1991): Resistance of Listeria monocytogenes to freezing in foods. Food Microbiol., 8: 63-68.

Rola, J.; Kwiatek, K.; Wojton, B. and Michalski, M. (1994): Incidence of Listeria monocytogenes in raw milk and dairy products. Medycyna Wet. 50: 323-325.

Rosenow, R.M. and Marth, E.H. (1987): Listeria, Listeriosis and dairy foods: a review. Culture Dairy Products J., 22 (4): 13-14.

Rota, C.; Yanguela, J.; Blanco, D.; Carraminana, J.J. and Herrera, A. (1992): Isolation and Identification of Listeria monocytogenes in fresh, ripened and processed cheese. Alimentaria, 28 (236): 5962. 
Ryser, E.T.; Marth, E.H. and Doyle, M.P. (1985): Survival of L. monocytogenes during manufacture and storage of Cottage cheese. J. Food Prot., 48: 746-750.

Shahamat, M.; Seaman, A. and Wood bine M.M. (1980): Survival of L. monocytogenes in high salt concentrations. Zbl. Bakt. Hyg. Abt. Orig. A. 246: 506-511.

Silva, M.C.; Hofer, E. and Tibana, A. (1998): Survival of L. monocytogenes in cheese produced in Rio de Janeiro, Brazil. J. Food Prot., 61(3): 354-356.

Slade, P.J. and Collins-Thompson, D.L. (1988): Incidence of Listeria species Ontario raw milk. Canad. Inst. Food Sci.Tech. J. 21: 425429.

Slade, P.J. and Collins-Thompson, D.L. (1990): Listeria, plasmids antibiotic resistance and food. Lancet 336: 1004.

Stone, D.L. (1987): A survey of raw whole milk for Campylobacter jejuni, Listeria monocytogenes and Yersinia enterocolitica. N.Z.J. Dairy Sci., 22: 257.

Terplan, G.; Schoen, R.; Springmeyer, W.; Degle, I. and Becker, H. (1986): L. monocytogenes in milk and milk products. Lebensmittel hygiene. Leithema: forschung und Praxis der Lebensmitte hygiene. Vol. 9-12. September 1986 in GarmischPartenkirchen. 1986, 272-303.

Van Kessel, J.S.; Karn, S. and Gorsici, L. (2004): Prevalence of Salmonellae, Listeria monocytogens and fecal coliforms in bulk tank milk on US dairies. J. Dairy Sci., 87: 2822-2830.

Vitas, A.I. and Garcia-Jalon, V.A. (2004): Occurrence of Listeria monocytogens in fresh and processed foods in Navarra (Spain). Int. J. Food Microbiol., 90: 349-356.

WHO working group (1988): Food borne Listeriosis. Bull. WHO 66: 421-428.

Zottola, E.A. and Smith, L.B. (1991): Pathogens in cheese. Food Microbiol. 8: 171-182. 